\title{
A review of advanced head and neck osteoradionecrosis
}

\author{
Erica J. Mayland, Larissa Sweeny \\ Department of Otolaryngology - Head and Neck Surgery, Louisiana State University Health Science Center - New Orleans, New \\ Orleans, LA 70809, USA.
}

Correspondence to: Dr. Larissa Sweeny, Department of Otolaryngology-Head and Neck Surgery, Louisiana State University Health Science Center - New Orleans, New Orleans, LA 70809, USA. E-mail: Iswee1@lsuhsc.edu

How to cite this article: Mayland EJ, Sweeny L. A review of advanced head and neck osteoradionecrosis. Plast Aesthet Res 2021;8:62. https://dx.doi.org/10.20517/2347-9264.2021.38

Received: 20 Apr 2021 First Decision: 19 Jul 2021 Revised: 19 Jul 2021 Accepted: 22 Oct 2021 Published: 5 Dec 2021

Academic Editors: Matthew Spector, Marten Basta Copy Editor: Xi-Jun Chen Production Editor: Xi-Jun Chen

\begin{abstract}
Osteoradionecrosis (ORN) of the head and neck can be a devastating complication following radiation therapy. ORN is associated with pain, chronic infection, and non-healing wounds. Radiation fibrosis, chronic infection, fistula formation, and necrotic tissues can make treatment challenging. The following review article is a narrative on the management of advanced head and ORN.
\end{abstract}

Keywords: Head and neck reconstruction, free flap, osteoradionecrosis

\section{INTRODUCTION}

The majority of patients with advanced head and neck cancer will receive radiation as part of their treatment ${ }^{[1]}$. For a subset of patients, radiation treatment has devasting side effects on the surrounding noncancerous tissues. One of the most crippling outcomes is the development of osteoradionecrosis (ORN) in the head and neck region. These cases can range from mildly symptomatic areas of exposed bone to pathological fractures, often leaving patients with disabling symptoms. The current understanding of ORN pathophysiology suggests a progression of hypovascular-hypoxic-hypocellular tissue. Changes in the metabolic homeostasis following radiation eventually progress to a state of hypoxia and hypovascularity. This ultimately leads to tissue breakdown and a non-healing wound ${ }^{[2]}$. 
The mean duration from completion of radiation therapy to the development of head and neck ORN is estimated at 22-47 months ${ }^{[3]}$. Dental extractions are commonly found to be a precipitating factor, with some studies noting a recent dental extraction in $50 \%-60 \%$ of cases ${ }^{[4,5]}$. The incidence of head and neck ORN throughout the literature ranges from 3\%-15\% ${ }^{[3,6]}$. While ORN can occur in multiple head and neck subsites, the mandible is the most common location ${ }^{[7]}$. The treatment of ORN is dependent on the severity of symptoms. The following narrative focuses on patients with advanced head and neck ORN with an emphasis on refractory cases requiring a free flap reconstruction.

\section{CLINICAL PRESENTATION}

Patients with advanced ORN commonly present with pain and exposed bone [Figure 1]. Patients with malignancy can also present with pain; therefore, an underlying malignancy should be ruled out prior to the start of ORN treatment. As ORN progresses, the bone may experience loss of density and strength, resulting in a pathologic fracture and/or orocutaneous fistula.

On panorex, early stages of ORN may present with findings of sclerotic bone or a poorly defined radiolucent lesion. Panorex may also show findings of cortication loss following dental extraction ${ }^{[8]}$. Common computed tomography (CT) findings of ORN include cortical defect or lucency, disorganized bony architecture, intraosseous air, and ultimately pathologic fracture ${ }^{[9]}$. When considering surgical intervention, CT imaging with $1 \mathrm{~mm}$ cuts of the maxillofacial skeleton is recommended ${ }^{[10]}$.

\section{NON-SURGICAL MANAGEMENT}

ORN treatment typically begins conservatively, with free flap reconstruction being reserved for refractory and advanced cases $^{[11]}$. Conservative therapy for the early-stage disease includes optimizing oral hygiene, eliminating dental disease, and the use of systemic antibiotics ${ }^{[12]}$. While often non-curative, these conservative interventions can provide symptomatic relief and slow progression. Antibiotics are commonly administered for acute infections or in the setting of chronically draining orocutaneous fistulas [Table 1].

Hyperbaric oxygen (HBO) therapy was introduced as a possible treatment for ORN in 1983 by Marx ${ }^{[13]}$. $\mathrm{HBO}$ therapy works by increasing local tissue oxygen concentrations, thereby promoting tissue epithelialization and bone regeneration. $\mathrm{HBO}$ therapy is sometimes used prophylactically in patients requiring dental extractions after radiation to potentially prevent ORN development. However, a randomized controlled trial of previously radiated patients requiring dental extraction found HBO therapy before dental trauma did not prevent ORN complications ${ }^{[14]}$. Currently, there are limited data demonstrating efficacy for the use of HBO therapy in the treatment of ORN [Table 2] $]^{[15-17]}$.

PENTOCLO is an antioxidant therapy that consists of pentoxifylline, tocopherol, and clodronate. Previous publications suggest improved wound healing when patients with ORN were administered PENTOCLO ${ }^{[1,19]}$. Pentoxifylline is thought to improve microcirculation, while tocopherol (vitamin E) acts as an antioxidant. Clodranate is a first-generation bisphosphonate that reduces osteoclast activity and stimulates osteoblasts. A retrospective study found that patients who received pentoxifylline and tocopherol after radiation had a lower incidence of $\mathrm{ORN}^{[20]}$. Dissard et al. ${ }^{[21]}$ also found that administration of the PENTOCLO regimen daily had a low side effect profile with high rates of symptom improvement when given antibiotics and steroids.

\section{SURGICAL MANAGEMENT}

ORN has significant quality of life (QOL) implications, including pain, infection, draining fistulas, and/or pathologic fractures. The decision to proceed with more invasive treatments is typically dictated by the 
Table 1. Summary of literature evaluating the efficacy of antibiotic therapy in radiated patients receiving dental extraction or implantation

\begin{tabular}{|c|c|c|c|c|c|}
\hline Ref. & Design & $n$ & Treatment & Outcomes & Conclusion \\
\hline $\begin{array}{l}\text { Sandhu et al. }{ }^{[55]} \\
\text { (2020) }\end{array}$ & Retrospective & 50 & $\begin{array}{l}\text { Post dental extraction Amoxicillin } \\
500 \mathrm{mg} 3 \times \text { /day for } 14 \text { days with } \\
\text { chlorhexidine } 2 \times \text { /day in radiated } \\
\text { patients }\end{array}$ & $\begin{array}{l}2 \% \text { developed ORN at } 18 \\
\text { months }\end{array}$ & $\begin{array}{l}\text { ORN incidence was comparable with } \\
\text { reported rates in the literature in } \\
\text { radiated patients receiving post- } \\
\text { extraction } \mathrm{Abx}\end{array}$ \\
\hline $\begin{array}{l}\text { Al-Bazie et al. } \\
\text { (2016) }\end{array}$ & RCT & 89 & $\begin{array}{l}\text { Ten days of Amoxicillin } 500 \text { mg q8h } \\
\text { and chlorhexidine before extractions }\end{array}$ & $\begin{array}{l}\text { No reported cases of ORN } \\
\text { at a mean of } 63 \text { months }\end{array}$ & $\begin{array}{l}\text { Perioperative Abx with antibiotic } \\
\text { mouthwashes are effective in } \\
\text { preventing ORN after extractions }\end{array}$ \\
\hline $\begin{array}{l}\text { Sultan et al. } \\
\text { (2017) }\end{array}$ & $\mathrm{RCT}$ & 26 & $\begin{array}{l}\text { Abx alone vs. Abx }+\mathrm{HBO} \\
\text { prophylaxis in radiated patients } \\
\text { receiving dental implants }\end{array}$ & $\begin{array}{l}\text { 1/13 from } \mathrm{HBO}+\mathrm{Abx} \\
\text { developed ORN, 0/13 from } \\
\text { Abx alone developed ORN } \\
\text { No difference in implant } \\
\text { survival }\end{array}$ & $\begin{array}{l}\text { No difference in outcomes between } \\
\text { Abx vs. Abx with } \mathrm{HBO} \text { in radiated } \\
\text { patients undergoing dental implants }\end{array}$ \\
\hline $\begin{array}{l}\text { Marx et al. } .^{[57]} \\
(1985)\end{array}$ & RCT & 37 & $\begin{array}{l}\text { Penicillin prior to dental extraction in } \\
\text { radiated patients vs. HBO }\end{array}$ & $\begin{array}{l}\text { ORN in } 5.4 \% \text { of } \mathrm{HBO} \text { group } \\
\text { and } 29.9 \% \text { of } \mathrm{Abx} \text { group }\end{array}$ & $\begin{array}{l}\text { Perioperative Abx did not decrease } \\
\text { ORN incidence at } 6 \text { months following } \\
\text { dental extraction }\end{array}$ \\
\hline
\end{tabular}

RCT: Randomized control trial; Abx: antibiotics; ORN: osteoradionecrosis; HBO: hyperbaric oxygen.

Table 2. Summary of literature evaluating the efficacy of hyperbaric oxygen therapy in patients with osteonecrosis

\begin{tabular}{|c|c|c|c|c|c|}
\hline Ref. & Design & $n$ & Treatment & Outcomes & Conclusion \\
\hline $\begin{array}{l}\text { Shaw et al. }{ }^{[14]} \\
\text { (2019) }\end{array}$ & $\mathrm{RCT}$ & 144 & $\begin{array}{l}\mathrm{HBO} \text { vs. no } \mathrm{HBO} \text { in radiated patients } \\
\text { requiring dental } \\
\text { extraction/implantation }\end{array}$ & $\begin{array}{l}\text { Incidence of ORN at } 6 \\
\text { months was } 6.4 \% \\
(\mathrm{HBO}) \text { vs. } 5.7 \% \text { (control) }\end{array}$ & $\begin{array}{l}\text { HBO for dental } \\
\text { extraction/implantation is } \\
\text { unnecessary }\end{array}$ \\
\hline $\begin{array}{l}\text { Bennett et al. } \\
\text { (2016) }\end{array}$ & $\begin{array}{l}\text { Cochrane } \\
\text { Review }\end{array}$ & 753 & $\begin{array}{l}\mathrm{HBO} \text { vs. no } \mathrm{HBO} \text { in patients with } \\
\text { non-healing wounds }\end{array}$ & $\begin{array}{l}\text { Improved healing of } \\
\text { radiated sockets after } \\
\text { extractions in } \mathrm{HBO} \\
\text { group }\end{array}$ & $\begin{array}{l}\text { Suggest improved healing following } \\
\text { HBO treatment in radiated sockets } \\
\text { after extractions }\end{array}$ \\
\hline $\begin{array}{l}\text { Teguh et al. }{ }^{[59]} \\
\text { (2009) }\end{array}$ & $\mathrm{RCT}$ & 19 & $\begin{array}{l}\text { Thirty sessions of } \mathrm{HBO} \text { after } \\
\text { completing head and neck RT vs. no } \\
\text { HBO }\end{array}$ & $\begin{array}{l}\text { Higher QOL scores in } \\
\text { HBO group (swallow, } \\
\text { saliva, and pain) }\end{array}$ & $\begin{array}{l}\text { Head and neck patients receiving } \mathrm{HBO} \\
\text { after RT had higher QOL scores }\end{array}$ \\
\hline $\begin{array}{l}\text { D'Souza et al. } \\
\text { (2007) }\end{array}$ & Retrospective & 23 & $\begin{array}{l}\text { HBO vs. no HBO for treatment of } \\
\text { ORN }\end{array}$ & $\begin{array}{l}12.5 \% \text { cure in } \mathrm{HBO} \\
\text { group, } 86 \% \text { cure rate in } \\
\text { non- } \mathrm{HBO} \text { group }\end{array}$ & $\begin{array}{l}\text { Small sample size but minimal benefit } \\
\text { from } \mathrm{HBO} \text { in the treatment of ORN }\end{array}$ \\
\hline $\begin{array}{l}\text { Bessereau et al. }{ }^{[61]} \\
(2010)\end{array}$ & $\mathrm{RCT}$ & 68 & $\begin{array}{l}\text { HBO vs. no HBO for treatment of } \\
\text { ORN }\end{array}$ & None & $\begin{array}{l}\text { Terminated early due to worse } \\
\text { outcome in } \mathrm{HBO} \text { arm }\end{array}$ \\
\hline
\end{tabular}

RCT: Randomized control trial; ORN: osteoradionecrosis; HBO: hyperbaric oxygen; QOL: quality of life.

patient's symptomology and the subsequent impact on QOL. Conservative surgical measures can include debridement, sequestrectomy, local tissue rearrangement, and marginal mandibulectomy. If conservative medical and surgical management fails to provide resolution or symptom relief, more invasive surgical interventions can be considered. Definitive surgery typically involves resection of the involved bone and soft tissues. The resulting defect often requires reconstruction with vascularized non-radiated tissue, typically in the form of a free flap ${ }^{[22-26]}$.

\section{FREE FLAP DONOR SITES}

When selecting a donor site for ORN reconstruction, one must consider the amount of soft tissue required and the length of bone needed for continuity.

\section{Fibula}

The fibula is the donor site used most commonly for free flap reconstruction of head and neck ORN. Advantages of the fibula free flap include a long segment of bone stock $(22-25 \mathrm{~cm})$, adequate pedicle length for tension-free anastomosis in the neck, and low donor site morbidity ${ }^{[27]}$. The fibula is harvested as a long 


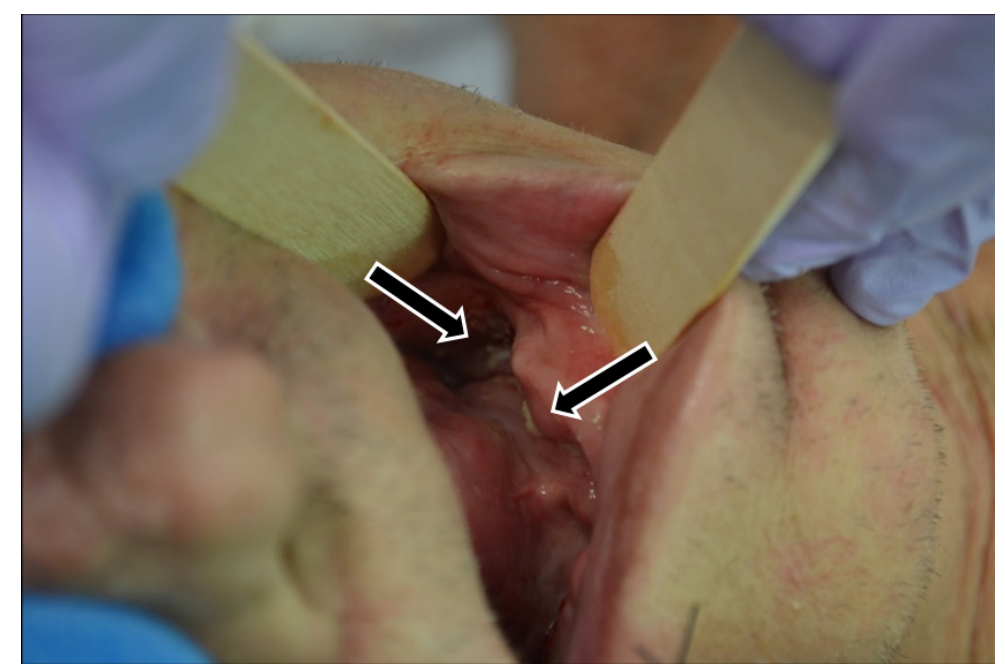

Figure 1. Physical examination of patient presenting with ORN following oral cavity radiation. Intraoral bone exposure (arrows) is a common finding in ORN patients often presenting as pain and oral phase dysphagia. ORN: Osteoradionecrosis.

segment of vascularized bone which allows for multiple osteotomies if needed to restore the natural contouring of the mandible or midface. The fibula has a high volume of cortical bone to bear the forces of mastication. Additionally, the bicortical bone of the fibula allows for dental implantation. The associated fasciocutaneous paddle has reliable perforators and can be harvested with the bone if coverage is needed for a mucosal or soft tissue defect. However, patients with severe peripheral vascular disease or those lacking three-vessel (anterior tibial, posterior tibial, peroneal) arterial runoff of the lower extremity may not be candidates for fibula reconstruction.

\section{Scapula}

In cases where the fibula is contraindicated or a large component of soft tissue is required, the scapula free flap is an ideal donor site. The lateral border of the scapula can reliably provide $10 \mathrm{~cm}$ of bone. Compared to the fibula, the scapula may have a thinner bone. The subscapular system often has a shorter pedicle length. However, the scapula tip is supplied by the angular artery, which originates from the thoracodorsal system. It has been reported that the angular artery is able to supply up to $10 \mathrm{~cm}$ of the lateral scapula border ${ }^{[28]}$. As a result, incorporation of the angular artery allows for increased pedicle length. The subscapular system can be extremely versatile, providing skin, muscle, and bone in a multitude of combinations. The latissimus can be incorporated and utilized for intraoral or external plate coverage. An additional chimeric component of rib and serratus muscle can be harvested with the serratus branch of the thoracodorsal vessels. The versatility of soft tissue combinations and bulk makes the scapular flap ideal for complex soft tissue reconstructions requiring a large volume of soft tissue and a shorter linear segment of bone ${ }^{[22]}$.

Dental implantation is also possible with scapula bone, and success rates are similar to the fibula ${ }^{[28]}$. In addition, the scapula may be advantageous in elderly patients who have significant peripheral vascular disease. Additionally, patients tend to ambulate sooner, possibly reducing postoperative complications ${ }^{[30]}$. The main disadvantages of the scapula are the shorter pedicle length, longer operative time, and intraoperative patient positioning.

\section{Osteocutaneous radial forearm}

The osteocutaneous radial forearm free flap (OCRFFF) is another less commonly used option to restore bony continuity. Similar to the scapula, the OCRFFF provides 10-12 cm of bone. However, the entire 
diameter of the radius bone cannot be harvested, limiting it to a single cortex following the harvest of $40 \%$ $60 \%$ of the radius circumference. Subsequently, there is insufficient bone stock to support dental implantation and necessitates prophylactic plating the radius to prevent fracture ${ }^{[31,32]}$. In addition, the fasciocutaneous tissue volume available is often less than the soft tissue available with the fibula.

\section{Fasciocutaneous and myocutaneous only donor sites}

In patients who do not require a vascularized segment of bone, a radial forearm or anterolateral thigh flap may be utilized. These flaps are applicable in ORN of the anterior skull base or lateral temporal bone for soft tissue coverage ${ }^{[33]}$. The radial forearm free flap is a fasciocutaneous flap that is thin and pliable, with reliable pedicle length and high rates of flap survival. However, this flap contains limited subcutaneous adipose in the majority of patients and lacks a muscle component making it inadequate for defects with large volume loss. Conversely, the anterolateral thigh free flap (ALT) may be composed of a combination of skin, adipose, fascia, or muscle. Adipose allows for improved volume retention as it is less subject to atrophy and contracture over time. However, depending on the thickness of the ALT subcutaneous adipose, it may provide more bulk than desired.

\section{OPERATIVE CONSIDERATIONS}

When reconstructing with an osseous donor site, consideration of bone segment length is important. For the periosteum to provide sufficient blood study, it is recommended that each bone segment measure at least $2 \mathrm{~cm}$ in length. The ability to create multiple osteotomies can improve facial contouring. However, it also reduces the length of the pedicle. This can create additional challenges in vessel depleted, radiated necks where contralateral vessels or vessels in the base of the neck (transverse cervical, dorsal scapular, or internal mammary) may necessitate a longer pedicle length.

\section{VIRTUAL SURGICAL PLANNING}

Virtual surgical planning (VSP) can be utilized to aid in flap design preoperatively. VSP allows for the creation of patient-specific cutting guides and plates, which may increase free flap accuracy and reduce operative times ${ }^{[3,34}$. The use of VSP is thought to improve bone-to-bone contact, reducing rates of malunion or nonunion and the subsequent sequalae ${ }^{[36,37]}$. The VSP software also provides information regarding the thickness of bone to aid in selecting sites for screw placement, ensuring adequate bone thickness, and reducing screw mobility and subsequent hardware extrusion ${ }^{[36-38]}$. VSP can also be used to mirror the healthy bone allowing for more symmetric reconstruction that more accurately reflects the anatomical positioning prior to developing ORN. Additionally, VSP can aid in planning the ideal orientation of the pedicle ${ }^{[39]}$.

\section{TECHNICAL CONSIDERATIONS}

Flap geometry and vessel selection can be quite challenging in patients with ORN. Tissue damage and fibrosis from prior radiation therapy and chronic infection can complicate dissection of recipient vasculature and impact the vessel wall integrity and caliber. A previous publication found that over half of free flap reconstructions for ORN required the use of the contralateral neck vessels ${ }^{\left[{ }^{[17]}\right.}$. Similarly, we have found improved free flap survival rates when using contralateral neck vessels ${ }^{[40]}$.

Reconstruction bar thickness varies among surgeons, ranging from 1 to $3 \mathrm{~mm}$ and averages $2.1 \mathrm{~mm}$. An example of a $2.0 \mathrm{~mm}$ reconstruction bar is shown in Figure 2A. Recent data suggests that reconstruction bar thickness may correlate with overlying soft tissue loss and hardware exposure rates, with a higher incidence of complications as reconstruction bar thickness increases ${ }^{[40]}$. 

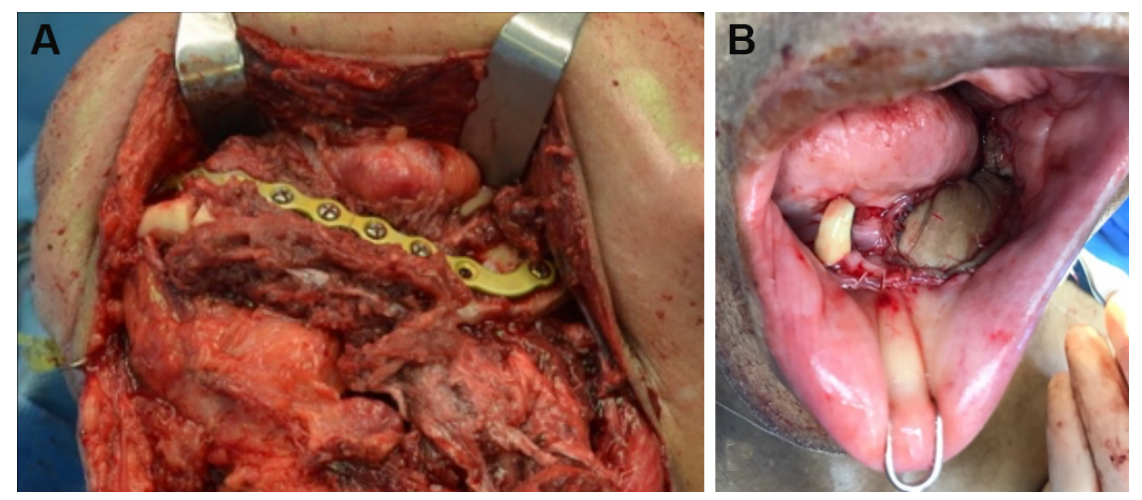

Figure 2. (A) Fibula free flap reconstruction of osteonecrosis defect extending from mandibular symphysis to ramus. (B) Example of the fasciocutaneous paddle of the fibula being to provide intraoral coverage for a mucosal defect.

Another variation in surgical design includes orientation and placement of the soft tissue component. Orientation of the fasciocutaneous paddle, in particular when a fibula donor site is used, can either be medial to the reconstructed bone segment or lateral to the reconstructed segment. When the soft tissue is oriented lateral to the hardware, it may provide an additional layer of soft tissue coverage over the reconstruction hardware. An example of a fasciocutaneous paddle that was brought medially into the floor of the mouth is depicted in Figure 2B. Interestingly, the medial orientation of the fasciocutaneous paddle was found to result in a lower incidence of postoperative bone exposure and required fewer postoperative tissue debridement and local flaps procedures ${ }^{[00]}$. The authors hypothesize that the medial orientation for the fasciocutaneous paddle reduces tension on the perforating vessels and provides protection from vascular insufficiency to the soft tissues ${ }^{[40]}$.

Dental implantation can significantly improve a patient's quality of life. Dental implantation success in ORN reconstruction has been cited around $95 \%{ }^{[4]}$. The literature cites similar complications rates with primary $v s$. secondary implantation in the setting of ORN. Secondary implantation has been found to correlate with higher fixed costs ${ }^{[41]}$, while primary implantation leads to a faster return of oral intake ${ }^{[41]}$. Implant success rates were found to be similar for fibula $v s$. scapula free flaps ${ }^{[42]}$.

\section{QUALITY OF LIFE}

Pain is thought to be a large contributor to poor quality of life for patients with advanced $\mathrm{ORN}^{[23,43]}$. Exposed nerve endings are subjected to infection and inflammation within a non-healing ORN wound. Free flaps are advantageous in their ability to provide coverage of exposed nerves and improve the blood flow to the area. One prospective study found a consistent reduction in pain-related domains following surgical resection and immediate free flap reconstruction of ORN, leading the authors to conclude that free flap reconstruction of advanced ORN improves $\mathrm{QOL}^{[43]}$.

In addition to pain, other QOL variables of concern for patients included speech, chewing, swallowing, and appearance ${ }^{[24,44-46]}$. The University of Washington Quality of Life (UW-QOL) survey is commonly utilized for the assessment of QOL following head and neck reconstruction with a free flap ${ }^{[23,24,43,46-48]}$. It was previously found that UW-QOL domain scores following free flap reconstruction for advanced ORN were higher for those patients who received dental implants, did not have a history of prior head and neck surgery, and did not develop a cancer recurrence ${ }^{[22]}$. In contrast, Sweeny et al. ${ }^{[2]}$ found UW-QOL domain scores were not impacted by ORN recurrence, anatomic subsite of the ORN, or donor tissue used for the reconstruction. A summary of QOL outcomes can be found in Table 3. 
Table 3. Summary of literature evaluating long-term quality of life outcomes in patients following microvascular reconstruction of osteonecrosis defects

\begin{tabular}{|c|c|c|c|c|c|}
\hline Ref. & Design & $n$ & Treatment & Outcomes & Conclusion \\
\hline $\begin{array}{l}\text { Sweeny et al. }{ }^{[22]} \\
(2021)\end{array}$ & Retrospective & 137 & $\begin{array}{l}\text { UW-QOL survey in patients following free } \\
\text { flap reconstruction for ORN }\end{array}$ & $\begin{array}{l}45 \% \text { reported no pain, } 28 \% \text { no swallowing abnormalities, } 93 \% \text { no } \\
\text { speech difficulty }\end{array}$ & $\begin{array}{l}\text { Data suggests a good return of function and QOL } \\
\text { following surgery }\end{array}$ \\
\hline $\begin{array}{l}\text { Lofstrand et al. }{ }^{[26]} \\
\text { (2018) }\end{array}$ & Retrospective & 41 & $\begin{array}{l}\text { SF-36, EORTC QLQ-C30, and QLQ- } \\
\text { H\&N35 questionnaires in cancer vs. ORN } \\
\text { patients }\end{array}$ & $\begin{array}{l}\text { ORN group had lower scores in swallowing and social eating } \\
\text { compared to cancer, but general QOL did not differ from the reference } \\
\text { population }\end{array}$ & $\begin{array}{l}\text { Cancer and ORN patients have similar QOL following } \\
\text { reconstruction with the exception of swallowing/social } \\
\text { eating }\end{array}$ \\
\hline $\begin{array}{l}\text { Jacobson et al. } \\
\text { (2013) }\end{array}$ & Retrospective & 30 & $\begin{array}{l}\text { PSS, SHI, QLQ-H\&N35, and EAT-10 } \\
\text { surveys in ORN after reconstruction }\end{array}$ & $\begin{array}{l}89 \% \text { had abnormal EAT-10 and SHI scores following reconstruction, } \\
\text { indicating abnormal speech and swallow }\end{array}$ & $\begin{array}{l}\text { Many patients remain unhappy with speech and } \\
\text { swallowing outcomes following reconstruction }\end{array}$ \\
\hline $\begin{array}{l}\text { Wang et al. }{ }^{[24]} \\
\text { (2009) }\end{array}$ & Retrospective & 15 & UW-QOL in ORN after reconstruction & $\begin{array}{l}70 \% \text { improved health related QOL after reconstruction, lowest scores } \\
\text { in speech/swallow/saliva }\end{array}$ & $\begin{array}{l}\text { Best scores in pain, but patients still have QOL issues } \\
\text { with speech, swallow, and saliva }\end{array}$ \\
\hline
\end{tabular}

UW-QOL: University of Washington Quality of Life; SF-36: Short Form Health Survey; EORTC QLQ-C30: European Organization for Research and Treatment of Cancer quality of life questionnaire; QLQ-H\&N35: European Organization for Research and Treatment of Cancer Quality of Life Questionnaire Head and Neck Module; PSS: Performance Status Scale; SHI: Speech Handicap Index; EAT-10: Eating Assessment Tool.

An important component of quality of life includes nutritional status. At 3 months following free flap reconstruction for advanced ORN, the rates of feeding tube dependence ranged from $13 \%-16 \%{ }^{[22,4]}$. When compared to their preoperative nutritional status, $47 \%$ of patients were tolerating a regular diet at 5 years following free flap reconstruction, and $31 \%$ had improvement in their diet status following free flap reconstructive surgery ${ }^{[22]}$. This data suggest that for a subset of patients, free flap reconstruction can lead to an improvement in diet function.

\section{SURGICAL COMPLICATIONS}

Complication rates following free flap reconstruction of head and neck ORN are cited between $30 \%-60 \% \%^{[16,26,44,46,49,50]}$. While most institutions cite free flap survival rates following head and neck reconstruction as $95 \%$ or greater, free flap survival rates following ORN reconstruction are cited at $89-93 \%{ }^{[2,46,50,51]}$. Additionally, it was found that patients undergoing free flap reconstruction for ORN had a higher incidence of late complications compared to patients undergoing free flap reconstruction for malignancy ${ }^{[3]}$. A retrospective study of 277 patients found that $24 \%$ of patients developed a postoperative fistula, $16 \%$ developed exposed bone, and $20 \%$ developed plate extrusion following free flap reconstruction for $\mathrm{ORN}^{[40]}$. These complications are attributed to poor tissue quality (radiation fibrosis, decreased perfusion) and a chronic inflammatory reaction in response to persistent infection and saliva exposure. Although uncommon, these complications can result in increased patient morbidity and healthcare $\operatorname{costs}^{[0,52,53]}$.

\section{ORN RECURRENCE}

ORN recurrence following free flap reconstruction is cited at $10 \%-14 \%$, with a median time to onset of 11 months ${ }^{[1722]}$. Poor wound healing and failure of osseointegration postoperatively were found to correlate with higher rates of ORN recurrence ${ }^{[22]}$. While the donor site selected for free flap reconstruction did not impact the recurrence of $\mathrm{ORN}^{\left[{ }^{44]}\right.}$. To avoid ORN recurrence at the surgical site, every attempt should be made to resect necrotic non-viable bone. The periosteum of the remaining bone should be inspected to ensure it is viable. The periosteum is a dense fibrous membrane with a rich vascular supply that 
envelopes the outer cortex of the bone and provides the superficial cortex with nutrients. The cortex should also be evaluated for viability. The cortex of healthy bone is dense, typically white in color, and will have visible bright red bleeding from trans-cortical capillaries. In addition, the bone marrow should be evaluated for viability. Healthy bone marrow is able to maintain its trabecular structure and will bleed bright red. Any bone which does not appear viable should be removed until viable bone is confirmed.

\section{CONCLUSIONS}

ORN is one of the most crippling complications following radiation for head and neck malignancies. The development of ORN has a significant impact on quality of life, leaving patients with disabling pain and chronic wounds. Free flap reconstruction is an integral part of the definitive management of advanced ORN. Although often effective at treating ORN, there remains a risk for postoperative wound complications and functional decline. Informed discussions with patients regarding expectations and anticipated outcomes and careful preoperative planning are essential in treating these complex cases.

\section{DECLARATIONS}

\section{Authors' contributions}

Made substantial contributions to conception and design of the study, analysis and interpretation, composition of manuscript, and final approval of manuscript: Sweeny L, Mayland EJ

\section{Availability of data and materials}

Not applicable.

\section{Financial support and sponsorship}

None.

\section{Conflicts of interest}

Both authors declared that there are no conflicts of interest.

\section{Ethical approval and consent to participate}

A written informed consent was obtained from all patients.

\section{Consent for publication}

Not applicable.

\section{Copyright}

(c) The Author(s) 2021.

\section{REFERENCES}

1. Trotti A, Bellm LA, Epstein JB, et al. Mucositis incidence, severity and associated outcomes in patients with head and neck cancer receiving radiotherapy with or without chemotherapy: a systematic literature review. Radiother Oncol 2003;66:253-62. DOI PubMed

2. Marx RE. Osteoradionecrosis: a new concept of its pathophysiology. J Oral Maxillofac Surg 1983;41:283-8. DOI PubMed

3. Danielsson D, Gahm C, Haghdoost S, Munck-Wikland E, Halle M. Osteoradionecrosis, an increasing indication for microvascular head and neck reconstruction. Int J Oral Maxillofac Surg 2020;49:1-6. DOI PubMed

4. Thorn JJ, Hansen HS, Specht L, Bastholt L. Osteoradionecrosis of the jaws: clinical characteristics and relation to the field of irradiation. J Oral Maxillofac Surg 2000;58:1088-93; discussion 1093-5. DOI PubMed

5. Aarup-Kristensen S, Hansen CR, Forner L, Brink C, Eriksen JG, Johansen J. Osteoradionecrosis of the mandible after radiotherapy for head and neck cancer: risk factors and dose-volume correlations. Acta Oncol 2019;58:1373-7. DOI PubMed

6. Moon DH, Moon SH, Wang K, et al. Incidence of, and risk factors for, mandibular osteoradionecrosis in patients with oral cavity and oropharynx cancers. Oral Oncol 2017;72:98-103. DOI PubMed

7. Reuther T, Schuster T, Mende U, Kübler A. Osteoradionecrosis of the jaws as a side effect of radiotherapy of head and neck tumour patients--a report of a thirty year retrospective review. Int J Oral Maxillofac Surg 2003;32:289-95. DOI PubMed

8. AlDhalaan NA, BaQais A, Al-Omar A. Medication-related osteonecrosis of the jaw: a review. Cureus 2020;12:e6944. DOI PubMed 
PMC

9. Jereczek-Fossa BA, Orecchia R. Radiotherapy-induced mandibular bone complications. Cancer Treat Rev 2002;28:65-74. DOI PubMed

10. Ren W, Gao L, Li S, et al. Virtual Planning and 3D printing modeling for mandibular reconstruction with fibula free flap. Med Oral Patol Oral Cir Bucal 2018;23:e359-66. DOI PubMed PMC

11. Oh HK, Chambers MS, Martin JW, Lim HJ, Park HJ. Osteoradionecrosis of the mandible: treatment outcomes and factors influencing the progress of osteoradionecrosis. J Oral Maxillofac Surg 2009;67:1378-86. DOI PubMed

12. Khan AA, Morrison A, Hanley DA, et al; International Task Force on Osteonecrosis of the Jaw. Diagnosis and management of osteonecrosis of the jaw: a systematic review and international consensus. J Bone Miner Res 2015;30:3-23. DOI PubMed

13. Marx RE. A new concept in the treatment of osteoradionecrosis. J Oral Maxillofac Surg 1983;41:351-7. DOI PubMed

14. Shaw RJ, Butterworth CJ, Silcocks P, et al. HOPON (hyperbaric oxygen for the prevention of osteoradionecrosis): a randomized controlled trial of hyperbaric oxygen to prevent osteoradionecrosis of the irradiated mandible after dentoalveolar surgery. Int J Radiat Oncol Biol Phys 2019;104:530-9. DOI PubMed

15. Sultan A, Hanna GJ, Margalit DN, et al. The use of hyperbaric oxygen for the prevention and management of osteoradionecrosis of the jaw: a Dana-Farber/Brigham and Women's Cancer Center Multidisciplinary Guideline. Oncologist 2017;22:343-50. DOI PubMed PMC

16. Hirsch DL, Bell RB, Dierks EJ, Potter JK, Potter BE. Analysis of microvascular free flaps for reconstruction of advanced mandibular osteoradionecrosis: a retrospective cohort study. J Oral Maxillofac Surg 2008;66:2545-56. DOI PubMed

17. Alam DS, Nuara M, Christian J. Analysis of outcomes of vascularized flap reconstruction in patients with advanced mandibular osteoradionecrosis. Otolaryngol Head Neck Surg 2009;141:196-201. DOI PubMed

18. Delanian S, Depondt J, Lefaix JL. Major healing of refractory mandible osteoradionecrosis after treatment combining pentoxifylline and tocopherol: a phase II trial. Head Neck 2005;27:114-23. DOI PubMed

19. Delanian S, Chatel C, Porcher R, Depondt J, Lefaix JL. Complete restoration of refractory mandibular osteoradionecrosis by prolonged treatment with a pentoxifylline-tocopherol-clodronate combination (PENTOCLO): a phase II trial. Int J Radiat Oncol Biol Phys 2011;80:832-9. DOI PubMed

20. Patel V, Gadiwalla Y, Sassoon I, Sproat C, Kwok J, McGurk M. Prophylactic use of pentoxifylline and tocopherol in patients who require dental extractions after radiotherapy for cancer of the head and neck. Br J Oral Maxillofac Surg 2016;54:547-50. DOI PubMed

21. Dissard A, P Dang N, Barthelemy I, et al. Efficacy of pentoxifylline-tocopherol-clodronate in mandibular osteoradionecrosis. Laryngoscope 2020;130:E559-66. DOI PubMed

22. Sweeny L, Mayland E, Swendseid BP, et al. Microvascular reconstruction of osteonecrosis: assessment of long-term quality of life. Otolaryngol Head Neck Surg 2021. DOI PubMed

23. Rogers SN, D'Souza JJ, Lowe D, Kanatas A. Longitudinal evaluation of health-related quality of life after osteoradionecrosis of the mandible. Br J Oral Maxillofac Surg 2015;53:854-7. DOI PubMed

24. Wang L, Su YX, Liao GQ. Quality of life in osteoradionecrosis patients after mandible primary reconstruction with free fibula flap. Oral Surg Oral Med Oral Pathol Oral Radiol Endod 2009;108:162-8. DOI PubMed

25. Shaha AR, Cordeiro PG, Hidalgo DA, et al. Resection and immediate microvascular reconstruction in the management of osteoradionecrosis of the mandible. Head Neck 1997;19:406-11. PubMed

26. Lofstrand J, Nyberg M, Karlsson T, et al. Quality of life after free fibula flap reconstruction of segmental mandibular defects. $J$ Reconstr Microsurg 2018;34:108-20. DOI PubMed

27. Kim JW, Hwang JH, Ahn KM. Fibular flap for mandible reconstruction in osteoradionecrosis of the jaw: selection criteria of fibula flap. Maxillofac Plast Reconstr Surg 2016;38:46. DOI PubMed PMC

28. Blumberg JM, Walker P, Johnson S, et al. Mandibular reconstruction with the scapula tip free flap. Head Neck 2019;41:2353-8. DOI PubMed

29. Yeh DH, Lee DJ, Sahovaler A, et al. Shouldering the load of mandible reconstruction: 81 cases of oromandibular reconstruction with the scapular tip free flap. Head Neck 2019;41:30-6. DOI PubMed

30. Dowthwaite SA, Theurer J, Belzile M, et al. Comparison of fibular and scapular osseous free flaps for oromandibular reconstruction: a patient-centered approach to flap selection. JAMA Otolaryngol Head Neck Surg 2013;139:285-92. DOI PubMed

31. Bigcas JLM, Bond J. Osteocutaneous radial forearm flap. Treasure Island (FL): StatPearls Publishing; 2021. Available from: https:// www.ncbi.nlm.nih.gov/books/NBK564384/ [Last accessed on 30 Nov 2021]

32. Kim JH, Rosenthal EL, Ellis T, Wax MK. Radial forearm osteocutaneous free flap in maxillofacial and oromandibular reconstructions. Laryngoscope 2005;115:1697-701. DOI PubMed

33. Chapchay K, Weinberger J, Eliashar R, Adler N. Anterior skull base reconstruction following ablative surgery for osteoradionecrosis: case report and review of literature. Ann Otol Rhinol Laryngol 2019;128:1134-40. DOI PubMed

34. Sharaf B, Levine JP, Hirsch DL, Bastidas JA, Schiff BA, Garfein ES. Importance of computer-aided design and manufacturing technology in the multidisciplinary approach to head and neck reconstruction. J Craniofac Surg 2010;21:1277-80. DOI PubMed

35. Largo RD, Garvey PB. Updates in head and neck reconstruction. Plast Reconstr Surg 2018;141:271e-85e. DOI PubMed

36. Avraham T, Franco P, Brecht LE, et al. Functional outcomes of virtually planned free fibula flap reconstruction of the mandible. Plast Reconstr Surg 2014;134:628e-34e. DOI PubMed

37. Chang EI. Long-term operative outcomes of preoperative computed tomography-guided virtual surgical planning for osteocutaneous free flap mandible reconstruction. Plast Reconstr Surg 2016;138:559e-60e. DOI PubMed

38. Patel H, Saadat N, Ho AS, Mallen-St Clair J. Virtual surgical planning for bisphosphonate-related osteonecrosis of the jaw: a valuable 
application in advanced cases. Cureus 2020;12:e9696. DOI PubMed PMC

39. Vieira L, Isacson D, Dimovska EOF, Rodriguez-Lorenzo A. Four lessons learned from complications in head and neck microvascular reconstructions and prevention strategies. Plast Reconstr Surg Glob Open 2021;9:e3329. DOI PubMed PMC

40. Mayland EJ SB, Curry JM, Wax MK, et al. Management and and outcomes of advanced head and neck osteonecrosis. Forthcoming 2021. Available from: https://journals.lww.com/cancerjournal/Fulltext/2016/12020/Antibiotic_protocol_for_the_prevention_of.22.aspx [Last accessed on 30 Nov 2021].

41. Menapace DC, Van Abel KM, Jackson RS, Moore EJ. Primary vs secondary endosseous implantation after fibular free tissue reconstruction of the mandible for osteoradionecrosis. JAMA Facial Plast Surg 2018;20:401-8. DOI PubMed PMC

42. Wilkman T, Husso A, Lassus P. Clinical comparison of scapular, fibular, and iliac crest osseal free flaps in maxillofacial reconstructions. Scand J Surg 2019;108:76-82. DOI PubMed

43. Danielsson D, Munck-Wikland E, Hagel E, Halle M. Quality of life after microvascular mandibular reconstruction for osteoradionecrosis-a prospective study. Head Neck 2019;41:2225-30. DOI PubMed

44. Baumann DP, Yu P, Hanasono MM, Skoracki RJ. Free flap reconstruction of osteoradionecrosis of the mandible: a 10-year review and defect classification. Head Neck 2011;33:800-7. DOI PubMed

45. Jacobson AS, Zevallos J, Smith M, et al. Quality of life after management of advanced osteoradionecrosis of the mandible. Int J Oral Maxillofac Surg 2013;42:1121-8. DOI PubMed

46. Chang EI, Leon P, Hoffman WY, Schmidt BL. Quality of life for patients requiring surgical resection and reconstruction for mandibular osteoradionecrosis: 10-year experience at the University of California San Francisco. Head Neck 2012;34:207-12. DOI PubMed

47. Rogers SN, Gwanne S, Lowe D, Humphris G, Yueh B, Weymuller EA Jr. The addition of mood and anxiety domains to the University of Washington quality of life scale. Head Neck 2002;24:521-9. DOI PubMed

48. Derek Lowe SR. University of Washington Quality of Life Questionnaire (UW-QOL v4) Guidance for scoring and presentation. Available from: https://www.entnet.org/wp-content/uploads/files/uw_qol_r_v4.pdf [Last accessed on 1 Nov 2021].

49. Sweeny L, Rosenthal EL, Light T, et al. Effect of overlapping operations on outcomes in microvascular reconstructions of the head and neck. Otolaryngol Head Neck Surg 2017;156:627-35. DOI PubMed

50. Cannady SB, Dean N, Kroeker A, Albert TA, Rosenthal EL, Wax MK. Free flap reconstruction for osteoradionecrosis of the jaws-outcomes and predictive factors for success. Head Neck 2011;33:424-8. DOI PubMed

51. Lee M, Chin RY, Eslick GD, Sritharan N, Paramaesvaran S. Outcomes of microvascular free flap reconstruction for mandibular osteoradionecrosis: a systematic review. J Craniomaxillofac Surg 2015;43:2026-33. DOI PubMed

52. Park L, Lilic N, Addison B, Patel R. Cost analysis of osteoradionecrosis. J Laryngol Otol 2017;131:303-8. DOI PubMed

53. Kelishadi SS, St-Hilaire H, Rodriguez ED. Is simultaneous surgical management of advanced craniofacial osteoradionecrosis costeffective? Plast Reconstr Surg 2009;123:1010-7. DOI PubMed

54. Li H, Tan MDM, Alexander S, Grinsell D, Ramakrishnan A. Comparative osteoradionecrosis rates in bony reconstructions for head and neck malignancy. J Plast Reconstr Aesthet Surg 2019;72:1478-83. DOI PubMed

55. Sandhu S, Salous MH, Sankar V, Margalit DN, Villa A. Osteonecrosis of the jaw and dental extractions: a single-center experience. Oral Surg Oral Med Oral Pathol Oral Radiol 2020;130:515-21. DOI PubMed

56. Al-Bazie SA, Bahatheq M, Al-Ghazi M, Al-Rajhi N, Ramalingam S. Antibiotic protocol for the prevention of osteoradionecrosis following dental extractions in irradiated head and neck cancer patients: a 10 years prospective study. $J$ Cancer Res Ther 2016;12:56570. PubMed

57. Marx RE, Johnson RP, Kline SN. Prevention of osteoradionecrosis: a randomized prospective clinical trial of hyperbaric oxygen versus penicillin. J Am Dent Assoc 1985;111:49-54. DOI PubMed

58. Bennett MH, Feldmeier J, Hampson NB, Smee R, Milross C. Hyperbaric oxygen therapy for late radiation tissue injury. Cochrane Database Syst Rev 2016;4:CD005005. DOI PubMed PMC

59. Teguh DN, Levendag PC, Noever I, et al. Early hyperbaric oxygen therapy for reducing radiotherapy side effects: early results of a randomized trial in oropharyngeal and nasopharyngeal cancer. Int J Radiat Oncol Biol Phys 2009;75:711-6. DOI PubMed

60. D'Souza J, Goru J, Goru S, Brown J, Vaughan ED, Rogers SN. The influence of hyperbaric oxygen on the outcome of patients treated for osteoradionecrosis: 8 year study. Int J Oral Maxillofac Surg 2007;36:783-7. DOI PubMed

61. Bessereau J, Annane D. Treatment of osteoradionecrosis of the jaw: the case against the use of hyperbaric oxygen. J Oral Maxillofac Surg 2010;68:1907-10. DOI PubMed 